\title{
An Investigation into the Nexus between Fiscal Policy, Foreign Direct Investment and Economic Growth in Nigeria
}

\author{
Patrick, OLOGBENLA \\ Obafemi Awolowo University, Ile Ife, Osun State, Nigeria \\ ologbenlapatrick@gmail.com
}

\begin{abstract}
The study examined the relationship between foreign direct investment and fiscal policy and the implication of the relationship on the Nigerian economic growth, the years under review were 1980 to 2019. Variables such as government expenditure, government revenue among others were used to proxy fiscal policy while data on foreign direct investment were used for FDI. The GDP growth rate was used as a proxy for the Nigerian economic growth. The study applied Autoregressive Distributed Lags estimating techniques. The result from the analysis indicated that the association between foreign direct investment and fiscal policy could not have a significant effect on the economic growth of Nigeria in the long run but, in the short run, the association was significant. The study recommends more collaboration between fiscal policy and foreign direct investment in such a way that it will promote the growth of the Nigerian economy.
\end{abstract}

Keywords: Fiscal Policy, Foreign Direct Investment, Economic Growth.

\section{Introduction}

Over the years, foreign direct investment has been a major incentive that peoples the Nigerian economic growth with its immense contributions to the revenue generation (Dada \& Abanikanda, 2021). Despite the huge revenue realized via foreign direct investment especially in the petroleum industry, the nature of fiscal policy practiced in Nigeria for the past two decades has been in form of deficit Ogege \& Boloupremo, 2020). That is, a major feature of fiscal policy in Nigeria over the years has been fiscal deficits. Proponents of fiscal deficit believe the excess of government expenditure over revue is to boost infrastructure and promote domestic production to maintain sustainable economic growth (Ogege, 2020; Arain, Qureshi, Suthar, Pirzado, Khanzada, Baloch, Memon, 2021). However, this case has not been the situation in Nigeria where economic growth has been falling and fluctuating in recent times. Nigeria within the last five years has witnessed two economic recessions in quick successions one in 2006 and the other one in 2020 (Yeboua, 2021). The poor performance of the country's economic growth and the rate of its fluctuation calls to question the roles of both foreign direct investment and fiscal policy in Nigeria. Although recent data have shown that capital inflow into Nigeria in form of FDI has been falling. For instance, FDI in Nigeria fell from 4.45 billion USD in 2016 to 3.3 billion USD in 2019 (World Bank, 2020). Around the same period, tax revenue fell by $6.7 \%$ and it was at the same period that Nigeria witnessed two economic recessions (CBN, 2019). The implication of this scenario is that it appears that there might be some connections among the three that is FDI, fiscal policy and Nigeria's economic growth.

For instance, the naira has undergone devaluation twice within the last five years and one of the cardinal objectives of this move is to promote FDI and boost domestic output that will propel economic growth (Babalola, \& Onikosi-Alliyu 2020). Despite all these efforts the FDI in Nigeria has been dwindling thus, compounding the negative effect on government revenue and hence limiting the usage of fiscal policy to put the country on the path of sustainable economic growth. Understanding the nexus between FDI and fiscal policy especially government revenue and expenditure has been adjudged to be very key to evaluating the impact of the two on economic growth (Wang, Xu, Qin, \& Skare, 2021). This nexus has generated different controversies in the literature ((Basuki, Purwaningsih, Soesilo, \& Mulyanto, 2020). For instance, some studies concluded that fiscal policy drives FDI while some studies concluded that the reverse is the case (Babalola \& Onikosi-Alliyu, (2020) from their assessment found out that the proceeds from FDI in form of revenue is a major driver of fiscal policy in Nigeria while Anichebe \& ACA, (2019) in their study viewed fiscal policy from tax revenue incentive given to foreign investors and concluded that this is a major driver of FDI into the country and hence they concluded that fiscal policy drives FDI. These debates have continued without any concrete consensus among the authors. Consequently, apart from evaluating the effect of both FDI and fiscal policy on the economic growth of Nigeria, the causality between fiscal policy and FDI will also be investigated to contribute to the existing literature on the dichotomy between the two. The rest of this seminar paper is 
divided into the literature review, methodology, results and discussions then, the conclusion and recommendations.

\section{Literature Review}

This aspect focuses mainly on the empirical literature around the topic, the theoretical literature is combined with the theoretical framework under the methodology of the paper. There have been diverse efforts around the relationship among FDI, fiscal policy and economic growth some of the most recent ones are discussed here. Ogege \& Boloupremo, (2020) examined the influence of the government fiscal policy on foreign direct investment (FDI) in the economy of Nigeria pre and post-military rule using data from 1981 to 2018. After the stationary test using the ADF method, the model was estimated with the application of the Ordinary Least Square technique and correlation analysis. Findings from the study showed that there is a positive and significant relationship between inflation and FDI especially during the Military Era in Nigeria. Furthermore, the findings also indicated that government expenditure impacted significantly on FDI during and before Military Eras. On the contrary, external debt did not have significant impacts on FDI in both periods. The same results were shown by the exchange rate. Notwithstanding, the Nigerian government has been making a series of efforts to promote FDI in the country via both foreign policy and macroeconomic policies. In a related study, Babalola \& Onikosi-Alliyu, (2020) using the annual data examined the impact of fiscal policy and its crowing out implication on capital inflow in Nigeria.

The FDI was identified as a proxy for capital inflow in the study whole the following variables namely, budget deficit domestic debt and external debt were all used to capture fiscal policy. Cointegration and error correction model was applied as the estimating technique. The result from the study indicated that budget deficit failed to have a crowding-out effect but rather crowing in effect on capital inflow both in the long and short ruin [period. Again the external debt showed a negative impact on capital inflow. In another perspective, Kyari, (2020) focused on the revenue side of fiscal policy by giving attention to petroleum tax. The study examined the impact of Nigerian petroleum tax incentives on foreign direct investments. The approach adopted was primary data and responses were collected via a questionnaire that was constructed using the Likert Scale method. The result of the analysis indicated that the petroleum tax incentive is an important method to attract foreign direct investment in Nigeria. In a related perspective that also centers on tax revenue Ogege (2020) adopting a qualitative research method, examines the sensitivity of foreign direct investment in Nigeria to taxation practices. The paper highlights that the tax incentive policy of the Nigerian tax system is a good driver of foreign investment in Nigeria. While the efficacy of taxation remains questionable, the paper whilst in conclusion recommends a justifiable level of fiscal incentives.

A stable political and economic climate is a panacea in achieving the desired effect. Anichebe \& ACA (2019) also focused on the tax revenue aspect of fiscal policy by examining the effect of revenue from the tax on the Nigeria FDI between 1981 and 2017. Sources of data include the CBN and NBS while the Ordinary Least Square estimating technique was adopted. The result showed that there is a significant relationship between tax revenue and FDI in Nigeria during the periods under the investigation. While VAT and Customs duties have a positive effect on FDI, company income tax and Personal income tax have negative impacts on the FDI. Olaniyi, Oyedokun, \& Ajayi, (2019) examined some tax incentives' impact on capital inflow in Nigeria. The tax incentive that was the focus are excise duties, customs duties, company income tax and value-added tax, the study focused on the period between 1994 and 2016. Both multiple regression and correlation analysis were used. Finding showed that excise duties, VAT and Custom duties incentives are very good drivers of capital inflow in Nigeria during the period under investigation. From the literature review, it is obvious that none of the studies actually combined all the three variables in their analysis. Again, despite the various findings in terms of the relationship between fiscal policy and FDI, none of the studies focused on examining the causality between the two. This study will be filling these gaps.

\section{Methodology}

This aspect of the paper discusses the theoretical framework, model specification, sources of data and definition of variables, estimating techniques and method of data analysis. 
Theoretical Framework (Two Gap Model): The theoretical under pining of this study is extracted from the two-gap model where both saving and foreign exchange gaps are identified as drivers of economic growth. This means that (I-S) and (M-X) are the main drivers of growth. $\mathrm{X}$ is export, $\mathrm{M}$ is import, I is Investment and S is savings. The less developed countries experienced this often where the investment is always at the excess of savings thereby creating a balance deficit and when the import is greater than export we have a deficit balance of payment. This approach relates capital inflow in form of FDI (foreign exchange gap) to the savings and investment gap which captured fiscal policy. All are used as drivers of economic growth as shown in the two-gap model. This model is adopted to generate the relationship between FDI, Fiscal policy and economic growth of Nigeria.

Model Specification: Following the theoretical framework and the empirical studies of Ogege, (2020). The model for this study is expressed as follows

$G D P=f(G E, G R, F D I, E X R, K)$

The growth rate model of the study is expressed as follows:

$G D P_{t}=\beta_{0}+\beta_{1} G E_{t}+\beta_{2} G R_{t}+\beta_{3} F D I_{t}+\beta_{4} E X R_{t}+\beta_{5} K_{t}+\varepsilon_{t}$

Where GDP is a gross domestic product of Nigeria to proxy economic growth, GE is government expenditure and GR is government revenue and both are proxies for fiscal policy. FDI is foreign direct investment, EXR is the exchange rate and $\mathrm{K}$ is capital formation both are control variables in the model.

Estimating Techniques: Equations 4.10 are estimated employing the cointegration analysis approach which followed the following four steps (1) testing for order of integration and stationarity of the variables utilizing unit root tests, (2) the cointegration analysis and (3) Granger Causality test.

Unit Root Testing: One of the initial conditions that must be fulfilled before ARDL is applied is the unit root test. The test suggests the stationarity status of all the variables to be used in the ARDL model. The variable must be either I(1) or I(0) orders of integration before ARDL can be applied. Two approaches to the unit root test namely the Augmented Dickey-Fuller (ADF) test and Phillips-Perron (PP) test are applied in this study.

Cointegration Tests: Cointegration tests are necessary to examine the stability or stationarity of a linear combination of the variables. The idea is that if a variable is not stationary, a linear combination with other variables might be. The implication of this is that long-run or co-movement do exist among such variables. An important requirement before ARDL cointegration can be applied is that the unit root test result must show that all the variables are I(1) or I(0). This is a condition that makes ARDL much more usable than other approaches of cointegration like the Johansen approach which made it mandatory for all the variables to be of order one that is I(1) before cointegration can be done.

Granger Causality: After the estimation of cointegration regression which is used to analyze relationships between FDI, fiscal policy and economic growth. The Granger causality test is conducted. This is because the existence of either unidirectional or bidirectional causality presupposes the existence of either long or shortrun relationships among the variables. The Granger causality test for two stationary variables is necessary for estimation of the empirical relationship between variables and our variables of interest here are FDI and fiscal policy variables namely; government expenditure and revenue.

Sources of Data: Data for this study will be sourced from both the Central bank of Nigeria and the World Bank. Precisely, data on both government expenditure and revenue was sourced from the CBN statistical bulletin 2020 edition, while data on FDI and economic growth was sourced from the World Bank table 2020 edition.

\section{Results and Discussion}

This section discusses the result obtained after the application of the ARDL estimating techniques. Notwithstanding, descriptive statistics and other pre estimating techniques were discussed first. 


\section{Descriptive Statistics}

Table 1: Descriptive Statistics

\begin{tabular}{lllllll}
\hline & GDPGR & GE & GR & FDI & EXR & K \\
\hline Mean & 3.176302 & 3.846069 & 3348767. & 2.541606 & 88.08500 & 36.19095 \\
Median & 4.200378 & 2.098885 & 4096.620 & 1.609715 & 97.01772 & 32.51772 \\
Maximum & 15.32916 & 9.448340 & 12294427 & 8.841062 & 306.0800 & 89.38105 \\
Minimum & -13.12788 & 0.911235 & 66.58000 & -0.738870 & 0.546781 & 14.90391 \\
Std. Dev. & 5.399415 & 2.904443 & 4731968. & 2.625479 & 86.75285 & 18.85074 \\
Skewness & -0.890935 & 0.727227 & 0.822255 & 1.025118 & 0.773783 & 1.092146 \\
Kurtosis & 4.762573 & 2.016977 & 1.920458 & 2.892897 & 2.923321 & 3.935148 \\
Jarque-Bera & 10.46954 & 5.136285 & 6.449710 & 7.024896 & 4.001398 & 9.409385 \\
Probability & 0.005328 & 0.076678 & 0.039762 & 0.029824 & 0.135241 & 0.009053 \\
Observations & 40 & 40 & 40 & 40 & 40 & \\
\hline
\end{tabular}

Note: GDPgr= GDP growth rate (\%), GE= Government expenditure (billion USD), GR= government revenue (Billion naira), FDI= foreign direct investment (\% of GDP), EXR= Exchange rate (naira per USD) $\mathrm{K}=$ gross capital formation (billion naira).

Source: Author's Computation (2021).

In table 1 average GDP growth rate stood at $3.176302 \%$ with minimum and maximum values of $-13.12788 \%$ and $15.32916 \%$ respectively. Mean values for government expenditure, government revenue, foreign direct investment, exchange rate and gross capital formation stood at 3.846069 billion US dollar, 3348767 billion US dollar, 2.541606\% of GDP, 88.08500 naira per US dollar and 36.19095 billion naira respectively. Minimum and maximum value stood at 0.911235 billion USD and 9.448340 billion USD for government expenditure, 66.58000 billion USD and 12294427 billion USD for government revenue, $-0.738870 \%$ of GDP and $8.841062 \%$ of GDP for foreign direct investment, 0.546781 naira per USD and 306.0800 naira per USD for the exchange rate, 14.90391 billion naira and 89.38105 billion naira for gross capital formation. Skewness statistics of $-0.890935,0.727227,0.822255,1.025118,86.75285$ and 1.092146 for GDP growth rate, government expenditure, government revenue, foreign direct investment, exchange rate and gross capital formation respectively as presented in table 1 revealed that all the variables except GDP growth rate are positively skewed, and Jarque-bera statistics revealed that only GDP growth rate, government revenue, foreign direct investment and gross capital formation are normally distributed.

Unit Root Test: The unit root test is called the stationarity test, it is one of the preconditions for the application of the ARDL. The variables must be either I91) or I(0) before ARDL can be applied. ADF approach to the test of unit root is adopted in the study. The results are presented in Table 2.

Table 2: Summary of Unit Root Test Result

\begin{tabular}{|c|c|c|c|c|c|}
\hline Variables & ADF Statistics & $\begin{array}{l}1 \% \\
\text { Value }\end{array}$ & Critical & 5\% Critical Value & $\begin{array}{ll}\text { Order } & \text { of } \\
\text { Integration } & \end{array}$ \\
\hline GDP gr & $-5.691246^{*}$ & -4.211868 & & -3.529758 & $\mathrm{I}(0)$ \\
\hline GE & $-6.204104^{*}$ & -4.219126 & & -3.533083 & I(1) \\
\hline GR & $-3.429314^{*}$ & -3.615588 & & -2.941145 & $\mathrm{I}(1)$ \\
\hline FDI & $-10.04513^{*}$ & -4.219126 & & -3.533083 & $\mathrm{I}(1)$ \\
\hline EXR & $-5.581314 *$ & -4.219126 & & -3.533083 & I(1) \\
\hline K & $-5.283010^{*}$ & -4.219126 & & -3.533083 & $\mathrm{I}(1)$ \\
\hline
\end{tabular}

Results on the table above indicate that all the variables are stationary at levels except the GDP gr that is stationary at levels. These results have already set a good tone for the application of ARDL. The next test is the cointegration test which is presented in table 3.

Table 3: ARDL Co-Integration Bound Test

\begin{tabular}{cll}
\hline F-Statistic & Lower Bound Critical Value & Upper Bound Critical Value \\
\hline 5.731707 & 2.62 & 3.79 \\
\hline
\end{tabular}

Note: Critical values are values at a 5\% significant level. Source: Author's Computation, (2021). 
For cointegration to exist among the variables the $\mathrm{F}$ statistics must produce a value that is greater than the critical values at both upper and lower bounds under $5 \%$ level is statistical significance. The result from the table has shown that the value of the F statistics is 5.731707 while the critical values at both the lower and upper bounds are 2.62 and 3.79 respectively. This result implies that cointegration exists. This has paved the way for the estimation of the long and short-run relationships among the variables.

Table 4: ARDL Short Run and Long Run form Estimation Result SHORT-RUN ESTIMATION

\begin{tabular}{lllll} 
Variable & Coefficient & Std. Error & t-Statistic & Prob. \\
\hline D(GDPGR(-1)) & 0.716450 & 0.464465 & 1.542526 & 0.1394 \\
D(GDPGR(-2)) & 0.578559 & 0.330660 & 1.749711 & 0.0963 \\
D(GDPGR(-3)) & 0.469969 & 0.210768 & 2.229794 & 0.0380 \\
D(GE) & $\mathbf{0 . 1 7 8 1 3 2}$ & $\mathbf{0 . 5 8 1 9 6 5}$ & $\mathbf{0 . 3 0 6 0 8 6}$ & $\mathbf{0 . 7 6 2 9}$ \\
D(GE(-1)) & 1.200687 & 0.819287 & 1.465527 & 0.1591 \\
D(GR) & $\mathbf{- 0 . 0 0 1 6 9 5}$ & $\mathbf{0 . 2 0 7 3 4 3}$ & $\mathbf{- 0 . 0 0 8 1 7 5}$ & $\mathbf{0 . 9 9 3 6}$ \\
D(FDI) & $\mathbf{1 . 2 3 6 1 9 9}$ & $\mathbf{0 . 4 9 3 0 8 3}$ & $\mathbf{2 . 5 0 7 0 8 1}$ & $\mathbf{0 . 0 2 1 4}$ \\
D(FDI(-1)) & 0.006927 & 0.347936 & 0.019909 & 0.9843 \\
D(FDI(-2)) & -0.339660 & 0.319813 & -1.062058 & 0.3015 \\
D(FDI(-3)) & 0.867242 & 0.333227 & 2.602557 & 0.0175 \\
D(EXR) & -2.745617 & 0.684051 & -4.013763 & 0.0007 \\
D(K) & -2.694287 & 1.411835 & -1.908358 & 0.0716 \\
CointEq(-1) & -1.975059 & 0.527699 & -3.742778 & 0.0014 \\
\multicolumn{1}{c}{ Cointeq = GDPGR - (-0.1622*GE } & $-0.0009 * G R+0.0435 * F D I-0.1242 * E X R$ & & \\
$\quad-1.3642 * K+6.4319)$ & & & & \\
LONG RUN ESTIMATION & & & & \\
Variable & & & \\
GE & Coefficient & Std. Error & t-Statistic & Prob. \\
GR & $\mathbf{- 0 . 1 6 2 1 8 0}$ & $\mathbf{0 . 5 3 9 4 9 2}$ & $\mathbf{- 0 . 3 0 0 6 1 7}$ & $\mathbf{0 . 7 6 7 0}$ \\
FDI & $\mathbf{- 0 . 0 0 0 8 5 8}$ & $\mathbf{0 . 1 0 4 9 5 3}$ & $\mathbf{- 0 . 0 0 8 1 7 7}$ & $\mathbf{0 . 9 9 3 6}$ \\
EXR & $\mathbf{0 . 0 4 3 5 0 9}$ & $\mathbf{0 . 3 9 6 9 4 6}$ & $\mathbf{0 . 1 0 9 6 1 0}$ & $\mathbf{0 . 9 1 3 9}$ \\
K & -0.124222 & 0.159989 & -0.776443 & 0.4470 \\
C & 1.364155 & 0.623262 & -2.188733 & 0.0413 \\
\hline
\end{tabular}

Source: Author's Computation, (2021).

Beginning with the result of the long-run analysis. The results have shown that none of the variables used in the proxy fiscal policy have a significant impact in the long run on the economic growth of Nigeria. These variables are government revenue and expenditure. In the same vein, FDI also failed to have a significant impact on economic growth. This is because of the Prob. of all these variables are greater than $5 \%$ hence they are not significant. The only variable with a significant, long-run relationship with the economic growth of Nigeria, in the long run, is an investment that is proxy by capital K. This result implies that the relationship between FDI, fiscal policy and economic growth in Nigeria is weak in the long run. In the short run, the result is different. FDI and exchange rate have a significant impact on the economic growth of Nigeria as the Prob is less than 5\%. Notwithstanding, the fiscal variables such as government expenditure and government revenue still continued to maintain a non-0signficance relationship with the economic growth. However, the error correction term is negative and significant. This means that the adjustment process from past disequilibrium to present equilibrium is in the right direction. 
Table 5: Post Estimation Test

\begin{tabular}{lll}
\hline $\begin{array}{l}\text { Normality Test } \\
\text { Statistics }\end{array}$ & Values & Probability \\
\hline Jarque-Bera Stat & 2.818628 & 0.244311 \\
Serial Correlation LM Test & & \\
Statistics & Values & Probability \\
F-statistic & 1.031482 & 0.1160 \\
Heteroscedasticity Test & & \\
Statistics & Values & Probability \\
Breusch-Pagan-Godfrey & 0.229994 & 0.9977 \\
\hline
\end{tabular}

Source: Author's Computation, (2021).

The results in the table above have shown that the estimated model produced a residual that is normally distributed since the Jarque Berra statistics are not significant. Again, both the F statistics of the serial correlation and test of Heteroskedasticity do not pass the test of statistical significance at $5 \%$ thus suggesting that the estimated model does not have the problems of serial correlation and heteroskedasticity.

\section{Analysis of Causal Relationship among Fiscal Policy, Foreign Direct Investment and Economic Growth} in Nigeria

Table 6: Granger Causality Test Result

\begin{tabular}{lcl}
\hline Null Hypothesis & F-statistics & Probability \\
\hline GE does not Granger Cause GDPGR & 0.30372 & 0.7401 \\
GDPGR does not Granger Cause GE & 2.67739 & 0.0436 \\
GR does not Granger Cause GDPGR & 0.41005 & 0.6670 \\
GDPGR does not Granger Cause GR & 1.21393 & 0.3099 \\
FDI does not Granger Cause GDPGR & 9.15351 & 0.0279 \\
GDPGR does not Granger Cause FDI & 2.42957 & 0.1037 \\
\hline
\end{tabular}

Source: Author's Computation, (2021).

The results from the pairwise granger causality have shown that there exists at least a unidirectional relationship between FDI and economic growth. The results show that FDI granger causes GDP growth rate. This means that the causality flows from the FDI to the GDP growth rate because the probability is 0.02 which is less than $5 \%$. The only relationship on the table that has less than $5 \%$ probability again is that of government expenditure and GDP growth rate. The Probability is 0.04 . This shows that the GDP granger causes GE. It means that the causality flow from GDP to GE. The implication is that there is at least a unidirectional causality between a fiscal variable and the economic growth of Nigeria.

\section{Discussion of Findings}

The result of the study showed that in the short run government expenditure exert a positive insignificant effect on GDP growth rate with a coefficient of 0.178132 ( $p=0.7629>0.05$ ) indicating that one percent increase in the government expenditure will lead to about 0.17 percent increase in GDP growth rate in the short run. The increase in GDP growth rate is a reflection of a growing economy while a decrease in GDP growth rate indicates a decline in economic growth. The implication of the result is that increase in the level of expenditure incurred by the government in the short run has potential for improving, however, such potential in Nigeria is yet to culminate into significant economic growth. Meanwhile in the long-run government expenditure showed an insignificant negative effect on the level of economic growth in the country. This result empirically validates the notion that government expenditure in Nigeria does not have long-run growth potential, given the relative fraction of government expenditure on recurrent relative to capital expenditure, that can culminate in improved productivity and economic output in the country. Result also showed that government revenue exert negative insignificant effect on GDP growth rate both on the short run and long run with coefficient of $-0.001695(\mathrm{p}=0.9936>0.05)$ and $-0.000858(\mathrm{p}=0.9936>0.05)$ respectively. 
This implies that a one percent increase in government revenue will lead to about a 0.0016 percent decrease in GDP growth rate in the short run. One percent increase in government revenue will also lead to about 0.00085 percent reduction in GDP growth rate. This result can be attributed to two things among others, first, the inherent mismanagement of public funds in the country due to a high level of corruption and system deficiencies, as such any increase in government revenue most time only gives room for further looting and mismanagement in the country. Secondly, an increase in government revenue especially in terms of tax tends to drain some level of productive potential out of both the formal and informal sector of the country, without the commensurate institutional and infrastructural quality in place for boosting output at the national level. Result in addition showed that foreign direct investment exert positive effect on GDP growth rate both in the short run and long run with coefficient of $1.236199(\mathrm{p}=0.0214<0.05)$ and $0.043509(\mathrm{p}=0.9139>0.05)$ respectively. In the short run inflow of foreign direct investment into the country has a significant incremental effect on the level of economic growth. However, in the long run, such an effect is not statistically significant though still positive. This reflects that the impact of foreign direct investment on the level of economic growth is more substantial in the short run. Finally, the result showed that there is an established causal relationship either between foreign direct investment and economic growth or between fiscal policy and economic growth. These results reflect that the previous level of foreign direct investment does not significantly contribute to the improved level of economic growth in Nigeria.

\section{Conclusion and Recommendations}

Conclusion: Based on the result of the proxy for the key variables foreign direct investment, fiscal policy and economic growth, this study concluded that foreign direct investment and fiscal policy have insignificant long-run impacts, on economic growth. Also, there is no causal relationship between foreign direct investment and economic growth as well as no causal relationship between fiscal policy and economic growth.

Policy Recommendations: In line with the outcome of this study, it is recommended that

- Government should ensure that revenue realized is adequately allotted to the productive sector of the economy to boost economic activities.

- Corruption needs to be controlled effectively as this will reduce the negative impact of government revenue on economic growth since funds will be used as planned on the productive economy thereby enhancing economic growth.

- The government needs to restructure the institutional characteristics that will attract foreign investors into the country to increase foreign direct investment as this will improve the economic activities and economic growth.

- Government should ensure that the proportion of capital expenditure to recurrent expenditure is increased to ensure an increase in the level of productive investment such that economic activities will be enhanced for greater economic growth.

\section{References}

Anichebe, A. S. \& ACA, A. (2019). Impact of Tax revenue on foreign direct investment in Nigeria. Journal of Business and Management, 217.

Arain, K., Qureshi, N. A., Suthar, V., Pirzado, A. A., Khanzada, A. H., Baloch, A. B. \& Memon, A. K. (2021). Impact of Foreign Direct Investment on Economic Growth in Pakistan. International Journal of Management (IJM), 12(4), 41-55.

Babalola, A. I. \& Onikosi-Alliyu, S. O. (2020). THE CROWDING-OUT EFFECT OF FISCAL POLICY ON CAPITAL INFLOWS IN NIGERIA. Facta Universitatis, Series: Economics and Organization, 043-056.

Basuki, A. T., Purwaningsih, Y., Soesilo, A. M. \& Mulyanto, M. (2020). The Effect of Fiscal Policy and Foreign Direct Investment on Regional Economy in Indonesia. Jurnal Ekonomi \& Studi Pembangunan, 21(1), 53-68.

Dada, J. T. \& Abanikanda, E. O. (2021). The moderating effect of institutions in foreign direct investment-led growth hypothesis in Nigeria. Economic Change and Restructuring, 1-27. 


\section{Journal of Social and Development Sciences (ISSN 2221-1152)}

Vol. 12, No. 4, pp. 1-8, December 2021

Kyari, A. K. (2020). The Impact of Petroleum Tax Incentives on Foreign Direct Investment Inflow: Evidence from Nigeria. International Journal of Energy Economics and Policy, 10(4), 516.

Ogege, S. \& Boloupremo, T. (2020). The Influence of Government Fiscal Policy on Foreign Direct Investment in Nigerian Economy. The Journal of Accounting and Management, 10(3).

OLANIYI, T. A., OYEDOKUN, G. E. \& AJAYI, R. O. (2019). Tax policy incentives on foreign direct investment in Nigeria. Fountain University Osogbo Journal of Management, 3(3).

Wang, X., Xu, Z., Qin, Y. \& Skare, M. (2021). Foreign direct investment and economic growth: a dynamic study of measurement approaches and results. Economic research-Ekonomska istraživanja, 1-24.

Yeboua, K. (2021). Foreign direct investment and economic growth in Africa: New empirical approach on the role of institutional development. Journal of African Business, 22(3), 361-378. 